\title{
EFEKTIVITAS LEMBAGA PEMASYARAKTAN DALAM MEMBINA NARAPIDANA DI INDONESIA: SEBUAH TINJAUAN PUSTAKA
}

\author{
Yoga Adi Pramudhito \\ Politeknik Ilmu Pemasyarakatan \\ Badan Pengembangan Sumber Daya Manusia Hukum dan Hak Asasi Manusia \\ Republik Indonesia \\ yogaadhito1998@gmail.com
}

\begin{abstract}
ABSTRAK
Naskah ini berjudul Efektivitas Lembaga Pemasyarakatan Dalam Membinaan Narapidana di Indonesia. Pada prinsipnya, semua terpidana yang menjalani pidana setelah melalui putusan pengadilan di tempatkan di Lembaga Pemasyarakatan, namun dalam lembaga ini banyak terjadi kendala, seperti kondisi Lembaga Pemasyarakatan yang memperihatinkan, dan juga dalam hal pembinaan narapidana. Adapun tujuan yang ingin diperoleh dari naskah ini adalah untuk memperoleh pemahaman mengenai efektivitas Lembaga Pemasyarakatan dalam membinaan narapidana. Penyelenggaran pembinaan dimulai dengan tahap pembinaan, tahap asimilasi dan tahap integrasi. Adapun kebijakan yang dapat diterapkan oleh pemerintah di masa yang akan datang antara lain Pengurangan jumlah Warga Binaan Pemasyarakatan, dan adanya sosialisasi terhadap masyarakat. Berdasarkan hasil penelitian tersebut dapat ditarik kesimpulan yaitu Kondisi pembinaan terhadap Warga Binaan Pemasyarakatan di Lembaga Pemasyarakatan dapat dikatakan tidak berjalan dengan maksimal hal ini dibuktikan dengan masih banyaknya permasalahan yang terjadi di Lembaga Pemasyarakatan di Indonesia.
\end{abstract}

Kata kunci : Efektivitas, Lembaga Pemasyarakatan, Narapidana, Pembinaan

\section{ABSTRACT}

This article is entitled The Effectiveness of Prisons in Fostering Prisoners in Indonesia. In principle, all convicts who undergo a crime after going through a court decision are placed in a correctional facility, however in this institution there are many obstacles, such as the worrisome conditions of the Penitentiary, and also in terms of guiding prisoners. The purpose of this article is to obtain an understanding of the effectiveness of correctional institutions in fostering prisoners. The implementation of coaching starts with the coaching stage, the 
assimilation stage and the integration stage. The policies that can be implemented by the government in the future include the reduction of the number of prisoners and socialization to the community. Based on the results of this research, it can be concluded that the conditions of guidance for the Correctional Assistance Citizens in Correctional Institutions can be said to be not running optimally, this is evidenced by the many problems that occur in correctional institutions in Indonesia.

Keywords : Effectiveness, Correctional Institutions, Prisoners, Development

\section{Latar Belakang}

Pemenjaraan adalah satu dari tiga jenis hukuman yang timbul daritindak pidana yang dilakukan oleh seseorang. Pemenjaraan adalah alternatif terakhir dari tindak pidana dengan salah satu tujuan untuk membuat hal buruk menjadi hal yang baik lagi. Pembangunan di penjara untuk narapidana harus memperhatikan semua yang ada faktor, seperti fasilitas, tenaga ahli, dan faktor lainnya dengan harapan itu pemenjaraan akan memberikan beberapa efek yang baik kepada narapidanadan tidak didiskriminasikan dari orang-orang yang tidak dihukum.

Penjara merupakan istilah yang sangat populer dalam sistem pidana di Indonesia. Penjara memiliki makna ganda yakni sebagai salah satu jenis sanksi pidana sebagaimana yang diatur dalam Pasal 10 KUHP dan sebagai tempat bagi terpidana untuk menjalani hukuman. Pidana penjara sudah dikenal sejak abad XVI. Akar pelaksanaan pidana penjara pertama-tama dijalankan di Inggris. Pada tahun 1955 kastil Bridewell di London digunakan oleh Raja Edward VI sebagai tempat berteduh bagi pengemis, gelandangan dan anak terlantar. Setelah itu di tempat-tempat lain di Inggris didirikan Bridewell-Bridewell yang menjadi bentuk-bentuk dari rumah penjara (houses of correction). Tempat tersebut awalnya digunakan untuk menampung pengemis, gelandangan dan anak terlantar tadi namun lama-kelamaan diubah fungsinya menjadi tempat penyiksaan (Koesnoen, 1964).

Pidana penjara menjadi jenis sanksi yang paling dominan diambil oleh hakim di Indonesia. Mengenai pidana penjara ini, Roeslan Saleh menyebutkan bahwa pidana penjara adalah pidana utama diantara pidana hilang kemerdekaaan dan pidana penjara ini dapat dijatuhkan untuk 
seumur hidup atau untuk sementara waktu (Setiady, 2010).

Dalam sistem hukum Indonesia dikenal dengan hukum kepidanaan, yakni sistem aturan yang mengatur semua perbuatan yang tidak boleh dilakukan (dilarang untuk dilakukan) oleh setiap warga negara Indonesia disertai sanksi yang tegas bagi setiap pelanggar aturan tersebut serta tata cara yang harus dilalui bagi para pihak yang berkompeten dalam penegakannya (Bisri, 2004).

Sementara itu, dalam Pasal 10 KUHP dikenal dua macam pidana yaitu pidana pokok dan tambahan, di mana salah satu pidana pokoknya adalah pidana penjara yang mana orang yang menjalani pidana penjara biasa disebut dengan sebutan narapidana. Tujuan memberi hukuman kepada narapidana, selain memberikan perasaan lega kepada pihak korban juga untuk menghilangkan keresahan di masyarakat. Caranya yaitu dengan menyadarkan mereka dengan cara menanamkan pembinaan jasmani maupun rohani. Dengan demikian, tujuan dari pidana penjara adalah selain untuk menimbulkan rasa derita karena kehilangan kemerdekaan, juga untuk membimbing terpidana agar bertaubat

dan kembali menjadi anggota masyarakat yang baik.

Pembinaan narapidana merupakan salah satu bagian terpenting dalam upaya penanggulangan kejahatan dalam sistem peradilan pidana Indonesia. Pembinaan adalah satu bagian dari proses rehabilitasi watak dan perilaku narapidana selama menjalani hukuman hilang kemerdekaan, sehingga ketika mereka keluar dari Lembaga Pemasyarakatan mereka telah siap berbaur kembali dengan masyarakat. Pemasyarakatan merupakan bagian akhir dari sistem pemidanaan dalam Tata Peradilan Terpadu adalah bagian Integral dari Tata Peradilan Terpadu (Integrated Criminal Justice system).

\section{Lembaga Pemasyarakatan}

merupakan bagian dari sistem peradilan pidana yang mengarah pada tujuan resosialisasi. Oleh karena itu, sebagai upaya pencapaian tujuan sistem peradilan pidana khususnya dalam resosialisasi diperlukan suatu sistem yang dikenal dengan sistem pemasyarakatan yang harus dilaksanakan dalam proses pembinaan terhadap Warga Binaan Pemasyarakatan. 


\section{Metode Penelitian}

Metode penelitian ini adalah Literature Review atau tinjauan pustaka. Studi literature review adalah cara yang dipakai untukmegumpulkan data atau sumber yang berhubungan pada sebuah topik tertentu yang bisa didapat dari berbagai sumber seperti jurnal, buku,internet, dan pustaka lain.Pada penelitian ini beberapa literature mengenai pembinaan narapidana di telaah lebih mendalam.

\section{Hasil dan Pembahasan}

\section{Pembinaan Narapidana di Lembaga Pemasyarakatan}

Secara etimologi, kata penjara berasal dari kata penjoro (kata dari bahasa Jawa) yang berarti taubat atau jera, dipenjara berarti dibuat Jera(Koesnoen, 1964). Penjara dipandang sebagai suatu tempat penjeraan bagi mereka yang pernah melaku-kan kejahatan. Hukuman penjara ditujukan kepada penjahat yang menunjukkan watak buruk dan nafsu bejat (Marpaung, 2008). Secara umum, di dunia terdapat tiga sistem kepenjaraan yakni:

a. Sistem Pensylavania. Sistem ini menekan-kan pada penutupan secara terasing terhadap narapidana agar insyaf dan menyesal atas perbuatannya dan agar merasakan pidananya. Menurut sistem ini narapidana dimasukkan dalam sel, narapidana mendapatkan pekerjaan di selnya masing-masing dan mendapat bacaan kitab Injil. Sistem Pensylvania banyak dianut negaranegara Eropa. Dalam sistem ini, narapidana tidak diberi kesempatan menerima pengunjung, dan tanpa diberi kesempatan berbicara dengan orang lain.

b. Sistem Auburn. Sistem ini pertama kali dilaksanakan di penjara Kota Auburn di Negara Bagian New York, kemudian karena sistem tersebut menunjukkan keberhasilan maka pada tahun 1925 sistem ini juga dilaksanakan di penjara Sing Sing. Menurut sistem ini, narapidana pada malam hari harus tinggal di dalam sel, sedangkan pada siang hari mereka melakukan pekerjaan secara bersama-sama, tetap antara narapidana satu dengan lainnya dilarang berbicara. Sistem ini banyak dipraktikkan di Amerika.

c. Sistem Irlandia. Sistem ini menghendaki agar para narapidana pada awalnya ditempatkan terusmenerus dalam sel. Tetapi kemudian dipekerjakan bersamasama. Pada tahap ke tahap narapidana diberikan kelonggaran 
untuk bergaul antara narapidana satu dengan lainnya. akhirnya setelah menjalani 3/4 (tiga perempat) dari lama pidana yang harus dijalani, narapidana dibebaskan dengan syarat (Widodo, 2009).

Jika mengacu pada teori efektivitas hukum yang menyebutkan efektivitas suatu peraturan harus terintegrasinya ketiga elemen hukum baik penegak hukum, substansi hukum dan budaya hukum masyarakat, sehingga tidak terjadi ketimpangan antara das solendan das sein (Achmad, 2009). Dari ketiga elemen hukum baik struktur hukum, substansi hukum, dan budaya hukum masyarakat yang belum dapat terpenuhi, maka dapat diketahui bahwa penyelenggaraan pembinaan di Lembaga Pemasyarakatan belum efektif. Relevan dengan teori efektivitas hukum, Romli Atmasasmita mengatakan faktor-faktor yang menghambat efektivitas penegakan hukum tidak hanya terletak pada sikap mental aparatur penegak hukum (hakim, jaksa, polisi dan penasihat hukum) akan tetapi juga terletak pada faktor sosialisasi hukum yang sering diabaikan (Romli, 2001).

Penjatuhan pidana bagi seorang pelanggar hukum pada hakikatnya tidaklah sebagai suatu perbuatan balas dendam oleh negara, melainkan sebagai imbangan atas tindak pidanayang telah dilakukannya. Dengan hal tersebut nantinya diharapkan akan menghasilkan kesadaran si-pelanggar hukum tersebut melalui pemberian pembinaan di dalam Lembaga Pemasyarakatan (LAPAS) dengan sistem Pemasyarakatannya.

LAPAS sebagai lembaga pembinaan yang mempunyai tugas penting yaitu rehabilitasi dan resosialisasi pelanggar hukum, bahkan sampai pada penanggulangan kejahatan (supresion of crime). Lebih lanjut, dalam Undang-undang Nomor 12 Tahun 1995 tentang pemasyarakatan dinyatakan bahwa sistem pemasyarakatan disamping bertujuan untuk mengembalikan Warga Binaan Pemasyarakatan sebagai warga yang baik juga bertujuan untuk melindungi masyarakat dari kemungkinan diulangi tindak pidana oleh narapidana.

Proses pembinaan yang dilakukan terhadap Warga Binaan Pemasyarakatan dimulai saat pertama kali narapidana tersebut masuk Lapas yang kemudian dilakukan pemeriksaan fisik sampai pada pada registrasi. Untuk tahap selanjutnya, Warga Binaan Pemasyarakatan ditempatkan dalam wisma khusus untuk menjalani proses Masa Pengenalan Lingkungan 
(MAPENALING) selama 7 hari (satu minggu). Setelah menjalankan proses MAPENALING, maka Warga Binaan Pemasyarakatan akan di masukan kedalam wisma untuk selanjutnya menjalankan proses pembinaan, yang terbagi ke dalam :

1. Tahap pembinaan, dilaksanakan pada 1/3 (satu per tiga) sampai $1 / 2$ (satu per dua) dari masa pidana, pada tahap ini pengawasan dilakukan sangat ketat (maximum security).

2. Tahap asimilasi, pelaksanannya dimulai $1 / 2$ (satu per dua) sampai $2 / 3$ (dua per tiga) dari masa pidana. Pada tahap ini pembinaan mulai dilakukan di dalam LAPAS ataupun di luar LAPAS.Pada tahap ini pengawasan agak berkurang (medium security).

3. Tahap integrasi, dilaksanakan setelah warga binaan pemasyarakatan menjalani 2/3 (duapertiga) masa pidana sampai dengan berakhirnya masa pidana.

Pada dasarnya, pemberian pembinaan di beberapa Lembaga Pemasyarakatan di Indonesia sudah mengacu pada prosedur yang ada yaitu UU No.12 Tahun 1995 tentang Pemasyarakatan sebagai dasar acuan pemberian Pembinaan dan PP No. 31
Tahun 1999 tentang Pembinaan Warga Binaan Pemasyarakatan. Namun, dalam beberapa hal masih saja ditemukan ketimpangan selama proses pembinaan di dalam Lapas tersebut.

\section{Lembaga Pemasyarakatan} (LAPAS) merupakan miniatur dari masyarakat luar, dengan kata lain apa yang ada di masyarakat luar pasti ada di dalam Lapas. Hal ini berarti masih adanya penggunaan narkoba di dalam Lapas, Tawuran antarwisma bahkan sampai pada oknum petugas sipir yang kedapatan melakukan pungli atau membiarkan narkoba masuk kedalam Lapas.

\section{Kebijakan Terhadap Pembinaan Narapidana}

Secara umum Lembaga Pemasyarakatan mengalami beberapa faktor yang dapat menghambat proses pembinaan, selain tidak seimbangnya penghuni terhadap Lembaga Pemasyarakatan, keadaan minimnya dana juga dijumpai dibeberapa Lembaga Pemasyarakatan (A. Josias \& Thomas, 2010). Dibeberapa Lembaga Pemasyarakatan yang mengalami keadaan kelebihan kapasitas hingga saat ini dan mengalami beberapa faktor penghambat proses pembinaan bagi narapidana yaitu Tidak semua warga binaan pemasyarakatan bersedia 
mengikuti pembinaan yang Dalam Pasal 9 Peraturan Pemerintah diprogramkan di Lembaga Nomor 31 Tahun 1999 tentang Pemasyarakatan, Keterbatasan sarana Pembinaan dan Pembimbingan Warga dan prasarana, Kurangnya tenaga Binaan Pemasyarakatan dijelaskan pengajar pembinaan.

bahwa tahapan-tahapan pembinaan DiIndonesia pelaksanaan narapidana secara sistematis sebagai penghukuman dan pembinaan berikut:

pelanggar hukum dilakukan dengan a. Pembinaan tahap awal sebagaimana mempergunakan filosofi dimaksud dalam Pasal 7 ayat (2) pemasyarakatan narapidana, yaitu suatu konsep yang bertujuan agar supaya pembinaan narapidana di dalam penjara mampu mengembalikan narapidana ke masyarakat dengan berhasil. Dengan demikian, keberhasilan tersebut diukur dari tidak diulanginya pelanggaran, dan bekas narapidana dapat terintegrasi kembali ke masyarakat sebagai warga negara yang taat hukum(Muhammad, 2007).

Pembinaaan narapidana sebagaimana yang dimaksud dalam Peraturan Pemerintah Nomor 31 Tahun 1999 tersebut dilakukan dengan program pembinaan dan pembimbingan yang meliputi kegiatan pembinaan dan pembimbing kepribadian dan kemandirian. Program pembinaan ini diperuntukkan bagi Narapidana dan Anak Didik Pemasyarakatan yang sedang menjalani proses pemasyarakatan. huruf a bagi Narapidana dimulai sejak yang bersangkutan berstatus sebagai Narapidana sampai dengan 1/3 (satu per tiga) dari masa pidana. Tahapan ini meliputi:

1) Masa pengamatan, pengenalan dan penelitian lingkungan paling lama 1 (satu) bulan;

2) Perencanaan program pembinaan kepribadian dan kemandirian;

3) Pelaksanaan program pembinaan kepribadian dan kemandirian; dan

4) Penilaian pelaksanaan program pembinaan tahap awal.

b. Pembinaan tahap lanjutan meliputi tahap lanjutan tahap pertama yang dimulai sejak berakhirnya pembinaan tahap awal sampai dengan 1/2 (satu per dua) dari masa pidana dan tahap lanjutan kedua, sejak berakhirnya pembinaan tahap lanjutan pertama sampai dengan $2 / 3$ 
(dua per tiga) masa pidana. pembinaan di LAPAS. Terkait dengan

Tahapan kedua ini meliputi:

1) Perencanaan program pembinaan lanjutan;

2) Pelaksanaan program pembinaan lanjutan;

3) Penilaian pelaksanaan program pembinaan lanjutan;

4) Perencanaan dan pelaksanaan program asimilasi.

c. Pembinaan tahap akhir dimulai sejak berakhirnya tahap lanjutan sampai dengan berakhirnya masa pidana dari narapidana yang bersangkutan, meliputi:

1) Perencanaan program integrasi;

2) Pelaksanaan program integrasi;

3) Pengakhiran pelaksanaan pembinaan tahap akhir.

Dalam Undang-undang Nomor 12 Tahun 1995 tentang Pemasyarakatan, pada Pasal 3 disebutkan bahwa fungsi sistem pemasyarakatan adalah "... menyiapkan warga bianaan pemasyarakatan agar dapat berintegrasi secara sehat dengan masyarakat, sehingga dapat berperan kembali sebagai anggota masyarakat yang bebas dan bertanggung jawab". Berdasarkan pasal tersebut, secara jelas mengenai gambaran keluaran (output) yang ingin dihasilkan dalam proses hal tersebut, selanjutnya dalam Pasal 5 dinyatakan bahwa sistem pembinaan pemasyarakatan dilaksanakan berdasarkan asas:

1. Pengayoman,

2. Persamaan perlakuan dan pelayanan,

3. Pendidikan,

4. Pembimbingan,

5. Penghormatan harkat dan martabat manusia,

6. Kehilangan kemerdekaan merupakan satu-satunya penderitaan, dan

7. Terjaminnya hak untuk tetap berhubungan dengan keluarga dan orang-orang tertentu.

Selain itu, sistem pemasyarakatan juga mengakui pentingnya peran serta masyarakat dalam proses pembinaan narapidana. Hal ini sesuai dengan Pasal 9 UU/12/1995 disebutkan bahwa:

(1).Dalam rangka penyelenggaraan pembinaan dan pembibingan Warga Binaan Pemasyarakatan, Menteri dapat mengadakan kerja sama dengan instansi pemerintah terkait, badan-badan kemasyarakatan lainnya, atau perorangan yang kegiatannya seiring dengan penyelenggaraan sistem pemasyarakatan 
sebagaimana dimaksud dalam Pasal

2 dan Pasal 3.

(2).Ketentuan mengenai kerja sama sebagaimana dimaksud ayat (1) diatur lebih lanjut dengan Peraturan Pemerintah.

\section{Fakta Lapas di Indonesia}

Dengan berubahnya sistem kepenjaraan menjadi sistem pemasyarakatan, berubah pula institusinya yang semula disebut rumah penjara menjadi lembaga pemasyarakatan. Perubahan tersebut berdasarkan Surat Instruksi Kepala Direktorat Pemasyarakatan No.J.H.G.8/506 tanggal 17 Juni 1964. Pada tahun 1995, dengan dikeluarkannya Undang-Undang No. 12 Tahun 1995 dalam Lembaran Negara RI Tahun 1995 No. 77 sebagai pengganti Reglemen Penjara 1917, sebutan narapidana juga berubah menjadi warga binaan pemasyarakatan. Istilah lembaga pemasyarakatan dapat disamakan dengan resosialisasi dengan pengertian bahwa segala sesuatunya ditempatkan dalam tata budaya Indonesia, dengan nilai-nilai yang berlaku di dalam masyarakat Indonesia(Jufri \& Anisariza, 2017).

Pembinaan yang dilakukan terhadap warga binaan pemasyarakatan didasarkan pada teori pemidanaan.
Menurut Muladi, secara tradisional teori-teori pemidanaan pada umumnya dapat dibagi kedalam tiga kelompok, yaitu: teori absolut (absolute theorien/vergelding theorien), teori tujuan (relatievetheorien/ doeltheorien), dan teori gabungan (verenegings theorien) (Muladi, 1998:6).

1. Teori Absolut

Menurut teori ini pidana dijatuhkan semata-mata karena orang telah melakukan suatu kejahatan atau tindak pidana.Pidana merupakan akibat mutlak yang harus ada sebagai suatu pembalasan kepada orang yangmelakukan kejahatan.Jadi dasar pembenaran dari pidana terletak pada adanya atau terjadinya kejahatan itu sendiri(Waluyo, 2000).

2. Teori Tujuan/teori Relatif

Menurut teori ini memidana bukanlah untuk memuaskan tuntutan absolut dari keadilan.Pembalasan itu sendiri tidak mempunyai nilai, tetapi hanya sebagai sarana untuk melindungi kepentingan masyarakat(Wulandari, 2016).

3. Teori Gabungan

Keberatan-keberatan terhadap teori pembalasan dan teori tujuan, dapat menimbulkan aliran ketiga yang mendasarkan jalan pikiran bahwa 
pidana hendaknya didasarkan atas interkoneksi antar lembaga penegak tujuan unsur-unsur pembalasan dan hukum untukmelaksanakan tahapan mempertahankan ketertiban masyarakat acara pidana menunjukkan differensiasi yangditerapkan secara kombinasi fungsional dari masing-masing dengan menitikberatkan pada salah satu lembaga.Pada titik ini terdapat unsurnya tanpa menghilangkan unsur kerentanan terjadinya ego sektoral dari yang lain, maupun pada semua unsur masing-masing lembaga.Terdapat yang ada(Jufri \& Anisariza, 2017). $\quad$ kecenderungan dalam praktik selama Lembaga pemasyarakatan ini LAPAS kurang memiliki kekuatan sebagai instansi yang melakukan tawar yang kuat terhadap tiga institusi pemenuhan dan perlindungan hak-hak asasi tersangka, terdakwa dan terpidana, mempunyai peran yang vital dalam proses penegakan hukum. Hal ini dikarenakan LAPAS merupakan instansi penegak hukum yang terlibat dalam proses penegakan hukum, sejak dalam tahap pra-adjudikasi, adjudikasi hingga tahap post adjukasi. Namun dalam prakteknya di Indonesia, posisi LAPAS sebagai salah satu sub sistem dalam sistem peradilan pidana masih belum seratus persen diakui sepenuhnya, baik oleh masyarakat maupun oleh instansi penegak hukum lainnya.Terbukti dan dapat dirasakan bahwa dalam realitasnya, LAPAS sampai saat ini masih belum diposisikan sebagaimana mestinya sesuai dengan tuntutan undang-undang yang notabene merupakan suara rakyat.Dalam bekerjanya sistem lainnya, kepolisian, kejaksaan, dan pengadilan (Datunsolang, 2013).

Selain itu, pada aspek pembinaan narapidana, orientasi pembinaan lebih bersifat top down approach.Pembinaan yang diberikan kepada narapidana, merupakan programprogram yang sudah ditetapkan dan narapidana harus ikut serta dalam program tersebut. Pendekatan top down tersebut juga didasarkan atas pertimbangan keamanan, keterbatasan sarana pembinaan dan pandangan bahwa narapidana hanya objek semata-mata. Jadi sebagai objek, eksistensi narapidana untuk ikut serta membangun dirinya atau membangun kelompok yang kurang diperhatikan. Pembinaan adalah paket yang datang dari atas. Sering pembinaan semacam peradilan pidana garis koordinasi dan 
atau kondisi LAPAS yang dalam bukunya(Sujatno \& Sudirman, bersangkutan (Harsono, 1995). 2008), memaparkan beberapa fakta

Seperti diketahui, keberhasilan terkait dengan LAPAS di Indonesia. upaya pembinaan, pengayoman Mulai dari penyimpangan seksual narapidana di dalam Lembaga dalam LAPAS dan juga penyeludupan Pemasyarakatan sangat tergantung barang-barang terlarang. Berbagai kepada faktor-faktor pendukung mekanisme penyaluran seksual dikenal lainnya, seperti: dukungan dan dalam kosakata masyarakat keikutsertaan masyarakat sampai Lapas/Rutan, antara lain istilah dengan kemauan politik pemerintah itu homobo'olabui, eentogan, memerian, sendiri. Namun demikian, banyak anak anakan, prostitusi, kendala yang dihadapi dalam proses penyalahgunaan ijin berobat dan lain pembinaan narapidana di LAPAS. sebagainya. Kesemuanya itu Dalam tulisannya, (Wowling, 2017) menunjukkan adanya mekanisme mengungkapkan beberapa problema penyaluran seksual yang muncul dalam yang menjadi kendala yang dihadapi masyarakat Lapas/Rutan.

petugas lembaga pemasyarakatan

Tak dapat dipungkiri bahwa dalam mengayomi serta mekanisme kontrol dan monitoring memasyarakatkan para narapidana, terhadap kinerja internal LAPAS tidak yakni diantaranya:

1. Kurangnya ruangan-ruangan untuk berjalan dengan baik, bahkan dapat dikatakan hampir tidak ada menempatkan narapidana khusus. pengawasan. Pada aspek inilah

2. Fasilitas dana pengayoman serta pentingnya fungsi kontrol dan pemasyarakatan (pembinaan) monitoring untuk memberikan jaminan narapidana yang sangat terbatas. kualitas (quality assurance)

3. Kurangnya tenaga ahli (psikolog, penyelenggaraan program pembinaan, sosiolog, ekonom, dan agawaman). pengamanan, dan pembimbingan dalam

4. Perangkat Peraturan yang sudah melaksanaan sistem pemasyarakatan. tidak sesuai lagi, dan

Mewujudkan

Lembaga

5. Sikap masyarakat yang tidak mau menerima eks narapidana.

\section{Pemasyarakat yang efektif.}

Merujuk pada pendapat yang Lebih lanjut, Pernyataan dari dikemukakan (Harsono, 1995), bahwa Adi Sujatno dan Dindin Sudirman pembinaan narapidana dengan top 
down approach tidaklah efektif sama sekali. Maka, orientasi pembinaan semacam itu harus diubah, agar pembinaan yang diberikan kepada narapidana berdaya guna dan berhasil guna, seperti yang diharapkan LAPAS.

Pembaharuan orientasi

pembinaan narapidana tersebut berubah dari top down approach menjadi bottom up approach. Bottom up approach adalah pembinaan narapidana yang berdasarkan kebutuhan belajar narapidana, setiap narapidana haruslah menjalani pre-test sebelum dilakukan pembinaan. Dari hasil pre-test akan diketahui tingkat pengetahuan, keahlian dan hasrat belajarnya. Dengan memperhatikan hasil pre-test, dipersiapkan materi pembinaan narapidana.

Pada pertengahan pembinaan, perlu diadakan mid test untuk mengetahui sejauh mana pembinaan bisa berhasil dan diakhiri pembinaan diadakan post-test, untuk keberhasilan pembinaan. Selain dilakukan perubahan pada orientasi pembinaan narapidana, penerapan Eight Principles of Effective Correctional Intervention juga akan dapat lebih mengintegrasikan pola pembinaan di LAPAS agar lebih efektif.
Namun demikian, kesemua hal tersebut harus dibarengi dengan upaya perbaikan dibeberapa aspek, diantaranya yakni: peraturan perundang-undangan, sarana personalia, sarana administrasi dan keuangan, dan sarana fisik Lembaga Pemasyarakatan.

Peningkatan koordinasi dan kerjasama antara Lembaga Pemasyarakatan dengan Instansi terkait dan keikutsertaan masyarakat dalam membina narapidana juga memegang peranan penting.Lebih lanjut, perlunya dilakukan peningkatan pengawasan (kontrol dan monitoring) terhadap kinerja internal LAPAS dalam melakukan penyelenggaraan program pembinaan, pengamanan, dan pembimbingan dalam melaksanaan sistem pemasyarakatan. Bentuk pengawasan tersebut dapat berupa pengawasan internal (pimpinan organisasi,Inspektorat Pemasyarakatan) dan pengawasan eksternal (pengawasan legislatif, pengawasan oleh masyarakat, dan pengawas oleh hakim pengawas dan pengamat)(Harsono, 1995).

\section{Kesimpulan}

Tulisan ini telah mengulas secara singkat persoalan yang menjadi kendaladalammelakukan pembinaan narapidana di LAPAS. Kecenderungan yang terjadi adalah proses. pembinaan 
yang dilakukan di LAPAS belum berjalan secara efektif. Kondisi pembinaan terhadap Warga Binaan Pemasyarakatan di Lembaga Pemasyarakatan dapat dikatakan tidak berjalan dengan maksimal. Hal ini dibuktikan dengan masih banyaknya permasalahan yang terjadi di Lapas seperti masih banyak narapidana yang menggunakan narkoba di dalam Lapas serta terdapat pungutan liar yang dilakukan oknum sipir dibeberapa Lembaga Pemasyarakatan di Indonesia.

Oleh karenanya, perludiupayakan beberapa hal berikut agar terwujudnya LAPAS yang efektif, yakni:

1. Perlu dilakukannya perubahan pada orientasi pembinaan narapidana;

2. Memerhatikan dan mengimplementasikan aspek Eight Principles of Effective Correctional Intervention dalam proses pembinaannarapidana;

3. Perbaikan sarana dan prasana LAPAS, diantaranya: peraturan perundang-undangan, sarana personalia, sarana administrasi dan keuangan, dan sarana fisik Lembaga Pemasyarakatan;

4. Peningkatan koordinasi dan kerjasama antara Lembaga Pemasyarakatan dengan Instansi terkait dan keikutsertaan masyarakat dalam membina narapidana, dan;

5. Peningkatan pengawasan (kontrol dan monitoring) terhadap kinerja LAPAS, baik pengawasan internal maupun pengawasan eksternal.

\section{Daftar Pustaka}

A. Josias, S., \& Thomas, S. (2010). Studi Kebudayaan Lembaga Pemasyarakatan di Indonesia. Bandung: Lubuk Agung.

Achmad, A. (2009). Menguak Teori Hukum (Legal Theory) \& Teori Peradilan (Judicial Prudence):Termasuk Interpretasi Undang-Undang (Legis Prudence) Volume 1. Jakarta: Pemahaman Awal Kencana.

Bisri, I. (2004). Sistem hukum Indonesia: prinsip-prinsip \& implementasi hukum di Indonesia. Raja Grafindo Persada.

Datunsolang, A. (2013). Datunsolang, A. (2013). Perlindungan Hak Asasi Manusia Bagi Narapidana dalam Sistem Pemasyarakatan (Studi Kasus Lembaga Pemasyarakatan Kelas II A Manado). Jurnal Hukum UNSRAT, 21(4), 891.

Harsono, C. (1995). Sistem Baru Pembinaan Narapidana. Jakarta: Djambatan.

Jufri, E., \& Anisariza, N. (2017). Pelaksanaan Asimilasi Narapidana di Lembaga 
Pemasyarakatan Terbuka

Jakarta. ADIL: Jurnal Hukum, 8(1). 1-26.

Koesnoen, A. (1964). Susunan Pidana

Dalam Negara Sosialis

Indonesia. Bandung: Sumur.

Marpaung, L. (2008). Asas-asas Teori Praktek Hukum Pidana. Jakarta: Sinar Grafika.

Muhammad, M. (2007). Kriminologi Kajian Sosiologi Terhadap Kriminalitas Perilaku Menyimpang dan Pelanggaran Hukum. Depok: FISIP UI Press.

Romli, A. (2001). Reformasi Hukum Hak Asasi Manusia dan Penegakan Hukum. Bandung: Mandarmaju.

Setiady. (2010). Pokok-Pokok Hukum Penitensier Indonesia. Bandung: Alfabeta.

Sujatno, A., \& Sudirman, D. (2008). Pemasyarakatan Menjawab Tantangan Zaman. Jakarta: Vetlas Production.
Waluyo, B. (2000). Pidana dan Pemidanaan. Jakarta: Sinar Grafika.

Widodo. (2009). Sistem PEmidanaan Dalam Cyber Crime. Yogyakarta: Laksbang Meditama.

Wowling, F. (2017). Wowiling, F. F. (2017). Pemenuhan Hak Narapidana Lapas Kelas Iia Manado Berdasarkan Pasal 14 Uu No. 12 Tahun 1995 Ditinjau Dari Perspektif Ham. Lex Privatum, 5(4).

Wulandari, S. (2016). Wulandari, S. (2016). Efektifitas Sistem Pembinaan Narapidana Di Lembaga Pemasyarakatan Terhadap Tujuan Pemidanaan. Jurnal Ilmiah Hukum Dan Dinamika Masyarakat,, 9(2). 